\title{
DEVELOPMENT OF NEW METHOD OF PRODUCTION OF HEALTHFUL COTTAGE COTTAGE CHEESE DESSERTS WITH USING VEGETABLE ADDITIVES IN THE FORM OF CRYOPASTES AND EXTRACTS
}

\author{
Viktoriya Pogarskaya \\ Department of Technology processing of fruits, vegetables and milk \\ Kharkiv State University of Food Technology and Trade \\ 333 Klochkivska str., Kharkiv, Ukraine, 61051 \\ viktoria.pogarskaya@ukr.net

\section{Raisa Pavlyuk} \\ Department of Technology processing of fruits, vegetables and milk \\ Kharkiv State University of Food Technology and Trade \\ 333 Klochkivska str., Kharkiv, Ukraine, 61051 \\ ktppom@ukr.net \\ Kateryna Balabai \\ Department of Technology processing of fruits, vegetables and milk \\ Kharkiv State University of Food Technology and Trade \\ 333 Klochkivska str., Kharkiv, Ukraine, 61051 \\ ekaterinabala@email.uat \\ Aleksey Pogarskiy \\ Department of Technology processing of fruits, vegetables and milk \\ Kharkiv State University of Food Technology and Trade \\ 333 Klochkivska str., Kharkiv, Ukraine, 61051

\section{Tetyana Stukonozhenko} \\ Department of Technology processing of fruits, vegetables and milk \\ Kharkiv State University of Food Technology and Trade \\ 333 Klochkivska str., Kharkiv, Ukraine, 61051 \\ tasichkayo@gmail.com

\section{Tetyana Abramova} \\ Technological department \\ College of processing and food industry of Kharkiv National Technical University of Agriculture \\ named after Petro Vasilenko \\ 51 Baricadna str., Kharkiv, Ukraine, 61098
}

\footnotetext{
Abstract

The aim of the work is the development of the new production method of healthful cottage cheese desserts with the record content of BAS of the prolonged storage term, based on sour-milk cheese in the nanosize form, using two types of vegetable additives as fruit-vegetable cryopastes and extracts. The new method includes BAS improvers, structure creators, coloring agents of fruit-vegetable fine-dyspersated vegetable additives of fruits and vegetables in the nanopaste form. At the same time vegetable additives as extracts of natural spices are used in the composition of desserts for prolonging the storage term of cottage cheese desserts and giving healthful properties to products.

There is used and developed the new method of making healthful cottage cheese desserts, based on sour-milk cheese without artificial food additives with the record content of BAS - phytocomponents with using fruit-vegetable fine-dyspersated cryoadditives that are a source of BAS, structure creators, coloring agents and with using extracts of natural spices. It is offered to use two types of vegetable additives as an innovation at producing cottage cheese desserts.
} 
The first type of additives - cryopastes of fruit-vegetable raw materials: carotene-containing vegetables (pumpkin, apricot, sea buckthorn), chlorophyll-containing ones (spinach), lemons with zest and apples. Comparing with initial raw materials, the BAS content of fruit-vegetable cryoadditives (especially, $\beta$-carotene, chlorophyll, L-ascorbic acid, soluble pectin) is higher in 2,5...3,5 times. The use of fruit-vegetable cryoadditives at producing cottage cheese desserts gives a possibility to exclude food admixtures and synthetic additives.

Introduction of the second type of vegetable additives as extracts of natural spices (cardamom and coriander, balm, lemon zest) in recipes of cottage cheese desserts favors the increase of their storage term in 2 times (comparing with an analogue). Such increase is connected with the high content of natural preservatives, detoxicants and substances with the bactericidal, bacteriostatic effect (aromatic, phenol compounds, tanning substances) in the aforesaid natural spices' composition.

The new method of producing healthful cottage cheese desserts differs from traditional ones by the fact that it includes mechanic destruction of cheese grain in the nanosize easily assimilated form. Fruit-vegetable cryoadditives are used as an innovation, as a source of BAS, natural thickeners and coloring agents and also extracts of natural spices for prolonging the storage term.

There are developed the recipes of three types of healthful cottage cheese desserts with cryoadditives of carotene-containing, chlorophyll-containing fruit-vegetable raw materials, and also citruses, apples and ginger. New desserts are in the easily-assimilated nanosize form, differ by the record content of natural BAS of fruits and vegetables. They exceed known world analogues by their chemical composition.

Keywords: healthful cottage cheese desserts, fruit-vegetable cryoadditives, sour-milk cheese, mechanolysis, extracts, natural spices, BAS. Aleksey Pogarskiy, Tetyana Stukonozhenko, Tetyana Abramova

\section{Introduction}

Healthful products include sour-milk ones with fruit-vegetable cryoadditives [1]. Among them combined milk-vegetable cottage cheese desserts, based on sour-milk cheese, are of the most demand of the population together with bioyoghurts. Such products combine in their composition healthful lactate bacteria and biologically active substances of vegetable raw materials [2, 3]. A shortcoming of combined sour-milk desserts is a low BAS content in vegetable raw materials. It is caused by the deficit of high-quality natural fillers at the market $[4,5]$ and traditional use of jam, fruits pastes, boiled fruits with a low BAS content at the expanse of hard technological processing regimes as fruit-vegetable additives $[6,7]$. At that, the composition of combined desserts includes different types of food additives (coloring agents, structure creators, aromatizers and so on [8-10]. The presence of these substances in the composition of products may be harmful for the human organism: cause allergy and other diseases $[2,3]$.

In this connection it is urgent to search for technological methods and to develop technologies of natural food additives that give a possibility to preserve the quality of fresh vegetable raw materials by the BAS content maximally, and to obtain fruit-vegetable additives that can be also used as natural coloring agents, thickeners, aromatizers at producing cottage cheese desserts. Introduction of such technologies will give a possibility to eliminate the deficit of high-quality fruit-vegetable fillers and also to widen the assortment of combined healthful cottage cheese desserts without or with a decreased amount of food additives [11, 12].

Promising raw materials for getting natural vegetable additives are: sea buckthorn, apricots, pumpkin, lemon with zest, apple, spinach, girasol and so on. These types of raw materials are traditional sources of BAS and prebiotic substances in population nourishment and are known for their healthy properties [3].

There was offered in the work to use cryo-processing and dyspersated communition of fruit-vegetable raw materials as a technological method at developing technologies of fruit-vegetable additives for healthful desserts. For this aim there was used cryogenic "shock" freezing, using liquid and gas-like nitrogen, and low-temperature comminution [2, 10, 13, 14].

It has been established for certain varities of fruits and vegetables, that the use of cryo-processing favors the essential decrease of cellular juice and BAS losses at defrost $[5,9,15,16]$. At the same time it has been demonstrated, that the use of cryo-processing results in better preservation of a texture of frozen purees and fruit-vegetable sorbets (cold desserts) [2, 17]. There has been established 
a direct dependence between the freezing speed of vegetable products and preservation degree of vitamins and other BAS [2]. The use of new types of fruit-vegetable fine-dyspersated additives as cryopastes at producing cottage cheese desserts and decrease of the content of traditional food additives in recipes need additional studies as to biochemical, enzymatic, oxidizing and other processes.

In this connection the aim of the work is the development of the new production method of healthful cottage cheese desserts, based on sour-milk cheese, without artificial admixtures, remarkable for the record content of BAS of vegetable raw materials at the expanse of using fruit-vegetable fine-dyspersated additives as cryopastes that are at the same time BAS improvers, structure creators and coloring agents.

\section{Materials and Methods}

Sour-milk skim cow cheese was used as a base for cottage cheese desserts in the work. It was produced by the Rogan milk industrial complex and Bogoduhiv milk plant. Pumpkin ("Muskatny"), apricots (“Chervonoschokiy"), sea buckthorn ("Krushinovydna”), girasol ("Interest”), lemon with zest ("Bianchetti"), spinach ("Victoria") (Fig. 1, 2) were used as raw materials for food cryoadditives. Apples "Semerenko") and ginger ("Rogatiy") were used as additives at producing cottage cheese desserts. Natural spices and medical vegetable raw materials: coriander "Yantar"), balm ("Icedora"), cardamom ("Amomum mohnatyiy"), chicory root ("Mokhovidniy") and lemon zest ("Bianchetti") were used as raw materials in the extract form.

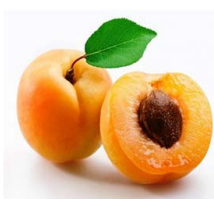

$a$

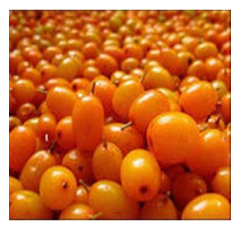

$e$

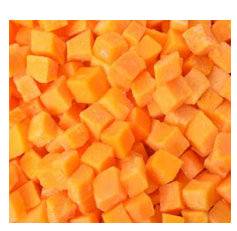

$i$

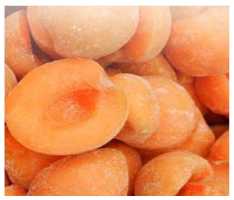

$b$

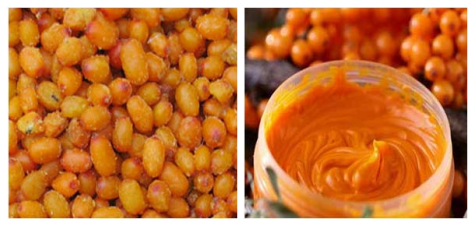

$f$

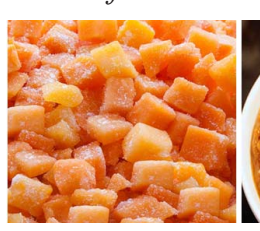

$j$

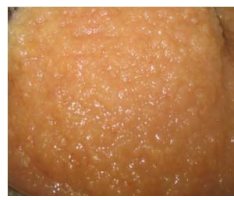

c

$g$

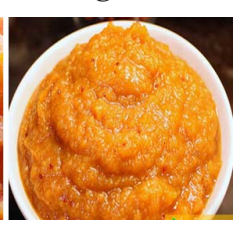

$k$

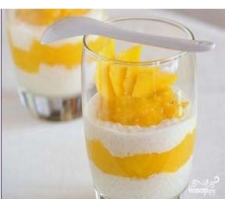

$d$

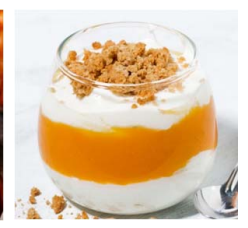

$h$

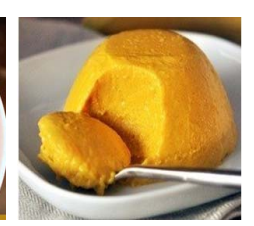

$l$

Fig. 1. Research objects: $a$ - fresh apricots, $b$ - frozen apricots, $c$ - puree of apricots, $d$ - cheese dessert with apricot puree; $e$ - fresh sea buckthorn, $f$ - frozen sea buckthorn, $g$ - puree of sea buckthorn, $h$ - cheese dessert with sea buckthorn puree; $i$ - fresh pumpkin, $j$ - frozen pumpkin, $k$ - pumpkin puree, $l$-cheese dessert with pumpkin puree

For attaining the aim, there was used mechanical processing of cheese grain as an innovation, accompanied by processes of mechanic activation and non-enzymatic catalysis of casein-calcium-phosphate complexes in the nanosize form. At that cheese products are enriched with healthful low-molecular substances of sour-milk cheese: a mass share of free amino acids, simple peptides and so on, easily assimilated by the human organism increases, protein molecules disintegrate to its low-molecular components ( $\alpha$-amino acids). Fruit-vegetable cryoadditives were used in new types of cottage cheese desserts as BAS improvers, natural structure-creators, coloring agents and aromatizers that give a possibility to exclude a necessity of using food admixtures and synthetic additives. For prolonging the storage term of new types of cottage cheese desserts and giving them 
an original taste and smell, there were used extracts of natural spices and medical vegetable raw materials (coriander, balm, cardamom, chicory root and lemon zest).

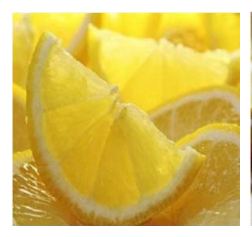

$a$

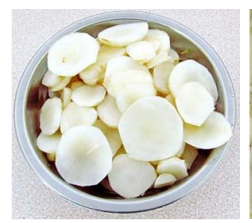

$e$

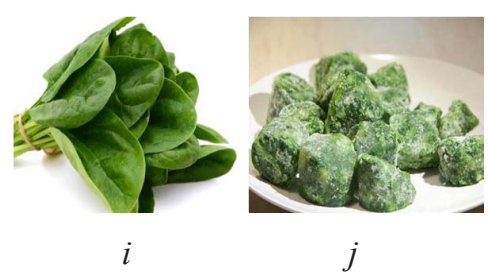

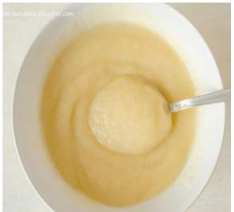

C

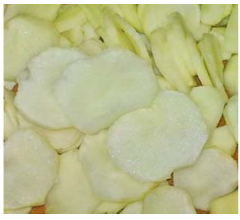

$f$

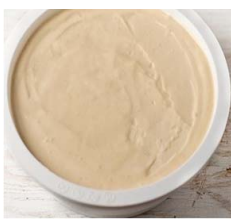

$g$

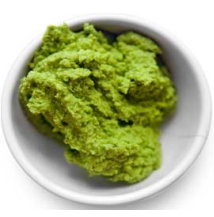

$k$

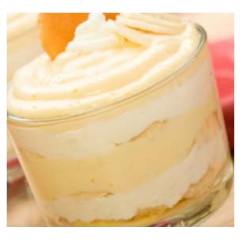

$d$

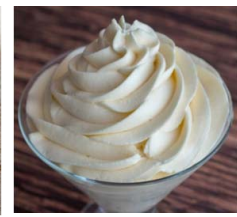

$h$

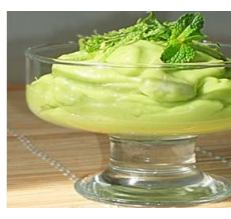

$l$

Fig. 2. Research objects: $a$ - fresh lemon, $b$ - frozen lemon with zest, $c$ - puree of lemon with zest, $d$ - cheese dessert with lemon puree; $e$ - fresh girasol, $f$ - frozen girasol, $g$ - girasol puree, $h$ - cheese dessert of girasol puree; $i$ - fresh spinach, $j$ - frozen spinach, $k$ - puree of spinach, $l$ - cheese dessert with spinach puree

The studies were conducted on the base of the research laboratory of "Innovative cryo- and nanotechnologies of vegetable additives and healthful products" of the Department of Technology processing of fruits, vegetables and milk of Kharkov State University of Food Technology and Trade (KSUFT, Ukraine).

The model studies at comminuting sour-milk cheese were realized without using cold by the fine-dyspersated comminutors «Robot Coupe» (France), «ThermoMix TM 5» (Germany). The studies of the influence of cryogenic «shock» freezing on the quality of fine-dyspersated cryoadditives of fruits and vegetables by BAS were realized using the modern stand equipment - cryogenic program "shock" freezer using liquid and gas-like nitrogen as a cooling agent and inert medium.

All fruits and vegetables were frozen with different speeds (from 1 to $20^{\circ} \mathrm{C} / \mathrm{min}$ ) to different final temperatures, lower than conventional one $-18{ }^{\circ} \mathrm{C}$. They all were frozen in the fast-freezing apparatus at temperature in the chamber $-60{ }^{\circ} \mathrm{C}$ to $-32 \ldots-35{ }^{\circ} \mathrm{C}$ within cut fruits and vegetables in pieces with thickness $0,5 \mathrm{~cm}$ and within whole berries. The temperature was registered by thermocouples, taken to the middle of a product in the modern apparatus - cryogenic program "shock" freezer using liquid and gas-like nitrogen. As it was demonstrated above, the indicated regimes play a principal role in inactivation of oxidizing enzymes and BAS preservation [2, 10]. Temperature indications in a product and freezing chamber were registered automatically each $20 \mathrm{~s}$.

Low-temperature fine-dyspersated comminution of frozen fruits and vegetables was conducted using the comminutors «SIRMAN» (Italy), «Robot Coupe» (France). The use of this equipment allowed to model technological processes for developing production nanotechnologies of new types of cottage cheese desserts and cryoadditives of fruits and vegetables, which quality by BAS content exceeds one of initial raw materials and of products and additives - analogues.

\section{1. Experimental procedures}

The content of biologically active substances in fruit-vegetable raw materials and new types of healthful cottage cheese desserts was determined by the following methods: 
- L-ascorbic acid - by the method of visual and potentiometric titration by the solution of 2,6-dichlorphenolindophenolate $\mathrm{Na}$;

- $\beta$-carotene - by Muri colorimetric method after removal of carotene from a product by an organic dissolver and its cleaning from associated coloring substances using column chromatography;

- low-molecular phenol compounds - by Folin-Denis colorimetric method in recalculation for rutin and by chlorogenic acid. The method is based on creating blue complexes at restoring tungsten acid under the effect of polyphenols with a reagent in the alkaline medium;

- tanning substances - by the titrimetric method in recalculation for tannin. The method is based on the property of tanning substances to oxidize at an indicator of indigo carmine;

- chlorophyll a and b-by the spectrophotometric method in acetone tinctures of the studied samples. The method is based on the difference of maximums in absorbing spectrums of chlorophyll in the red zone.

The content of cellulose was determined by Ermakov method, based on oxidation and dissolution of different substances, especially ones, associated with cellulose, at processing by the solution of nitrogen acid in ethyl alcohol and water solution of alkaline [17].

The mass share of pectin substances was determined by the method, based on hydrolysis of pectin substances and sedimentation of polygalacturonic acid as cellulose sodium pectate.

The mass share of protein in sour-milk cheese and new types of healthful cottage cheese desserts was determined by Kjeldahl nitrogen-metric method [18]. It is based on determination of an amount of protein nitrogen, formed at destruction of amino acids included in the protein composition. The mass share of bound and free a-amino acids was controlled by the method of ion-exchange chromatography using the automatic analyzer of amino acids.

\section{Results}

There was developed the new production method of fruit and vegetable cottage cheese desserts for healthy nutrition of sour-milk cheese without food admixtures and synthetic components. Two types of vegetable additives were used as an innovation: cryopastes of fruit and vegetable raw materials and extracts of natural spices. Cryoadditives of fruit and vegetable raw materials are in the nanosize form and act as BAS improvers, structure creators, coloring agents and natural thickeners. Vegetable additives as extracts of natural spices are used as natural preservatives, detoxicants and favor prolonging the storage tem of ready product. New types of desserts differ from traditional ones by the record BAS content - healthy phytocomponents that favor strengthening of the population health and immunity increase.

The quality and BAS content in fine-dyspersated fruit and vegetable additives in the cryopaste form of caroten-, chlorophyll-containing fruit and vegetable raw materials, such as citruses, apples, ginger were studied. They were compared with ones of fresh raw materials. It has been demonstrated, that comparing with fresh fruit and vegetable raw materias, cryoadditives not only preserve all vitamins, but also release hidden BAS forms 2,5...3,5 times more completely. It has been established, that cryoadditives contain the essential amount of BAS, especially $\beta$-carotene, chlorophyll $\mathrm{a}$ and $\mathrm{b}$, phenol compounds, tanning substances, vitamin $\mathrm{C}$. The mass share of these BAS, contained in $100 \mathrm{~g}$ of cryoadditives, can satisfy from 1 to 7 daily norms of an adult human in them. At the same time the use of fruit-vegetable cryoadditives in the nanosize form that are a source of BAS, natural thickeners, coloring agents, aromatizers at producing cottage cheese desserts gives a possibility to exclude food additives and synthetic admixtures.

It is known, that cottage cheese desserts relate to easily spoiled products. Their storage life at temperature $+4 \ldots+6{ }^{\circ} \mathrm{C}$ is 36 hours, and at temperature $0 \ldots+2{ }^{\circ} \mathrm{C}-14$ days. For increasing the storage life, it is recommended to introduce additives of natural spices in the form of water-alcohol extracts as recipe components in new types of cottage cheese desserts. Cardamom, coriander, balm, chicory root and lemon zest were used as components for producing extracts. It is known, that these raw materials contain natural preservatives, detoxicants, substances with the bactericidal and bacteriostatic effect in their composition. It is connected with the high content of aromatic substances, phenol compounds and tanning substances in them. It has been demonstrated, that introduction of extracts from the aforesaid natural spices in the recipes of cottage cheese desserts 
favors the increase of the storage term of desserts in 2 times, comparing with the control (without using extracts). It has been established, that the new types of desserts have an original taste and smell of a natural product and natural brightly expressed color.

The recipes of carotene-containing cottage cheese desserts with using fruit and vegetable cryoadditives of apricots, sea buckthorn, pumpkin and citruses (especially, lemons with zest) were developed. The total amount of cryoadditives in desserts was from 20 to $30 \%$ that is $200 \ldots 300 \mathrm{~g}$ of cryoadditives for $1 \mathrm{~kg}$ of a dessert. The recipes differed by different amounts of the aforesaid components and were controlled, fist of all, by organoleptic parameters. But a parallel criterion at developing the recipes of cottage cheese desserts was indices of the content of $\beta$-carotene, phenol compounds and L-ascorbic acid. According to recommendations of FAO/WHO and Nutrition institute of WHO of Russia and Ukraine, $100 \mathrm{~g}$ of healthy products must contain from 0,5 to $2 / 3$ of the daily need of the human organism in these substances.

Products with an increased composition and BAS amount are related in international practice to the category of healthy ones, favoring population health strengthening.

It must be noted, that organoleptic parameters, such as outlook, color, consistence (or texture), taste, smell are subjective. Each taster perceives them individually. It is known, that reliable methods of quality estimation are objective parameters, obtained using chemical conventional research methods, included in different SSU for food products.

The recipes of fillers for cottage cheese desserts with chlorophyll-containing vegetables include cryopuree of spinach, apples, lemons with zest and ginger. They differ by different ratios of these components. The third line of fillers for cottage cheese desserts includes cryopuree of apples, lemons with zest and ginger and karkade extract, that differ by different ratios, as a main component.

All recipes of fillers for cottage cheese desserts include extracts of natural spices: coriander, balm, cardamom, chicory root and lemon zest.

Both the recipes of cottage cheese desserts and fillers are "know-how" of the authors.

All cottage cheese desserts have an original natural taste and smell, inherent to the used natural spices, they are remarkable for pleasant organoleptic parameters. It has been established, that cottage cheese desserts contain the daily norm of P-active phenol compounds and 0,5-0,75 of the daily need in $\beta$-carotene, chlorophyll and L-ascorbic acid. New desserts are in the easily assimilated nanosize form, are remarkable for the record content of BAS of fresh fruits and vegetables. Their chemical composition exceeds known world analogues, so they are recommended as healthy products for strengthening health of all population layers.

The developed healthy cottage cheese desserts with the record content of natural BAS are recommended for immune prophylaxis of the population, especially, children and elderly people.

The new type of producing healthful cottage cheese desserts with using two types of vegetable additives - fruit and vegetable cryopastes and extracts of natural spices were probated under production conditions at the enterprises of city Kharkiv and region: "Bogoduhiv milk plant" LTD, "IF Khladoprom”, “Cryas Plus” RPE, CUSE "Plus LTD” (Ukraine).

\section{Conclusions}

There has been scientifically grounded and experimentally proved a possibility of using fine-dyspersated fruit and vegetable cryoadditives at producing cottage cheese desserts as an innovative method of structure creation, giving natural color (green, yellow-orange) to desserts, enrichment with BAS, especially carotenoids, chlorophylls, phenol compounds, tanning and prebiotic substances. The use of fruit-vegetable cryoadditives at producing cottage cheese desserts gives a possibility to exclude food admixtures and synthetic additives.

It has been demonstrated, that introduction of the second type of natural vegetable additives as nanoextracts from natural spices (cardamom, coriander, balm and lemon zest) in the recipes of cottage cheese desserts favors not only enrichment of a product with unsaturated aromatic and phenol compounds, but also the increase of their storage life in 2 times, comparing with control samples.

There have been developed the recipes of healthful cottage cheese desserts with cryoadditives and carotene-containing, chlorophyll-containing fruit and vegetable raw materials, citruses, apples, ginger and also with vegetable additives as extracts of natural spices. It has been demon- 
strated, that new cottage cheese desserts are in the nanosize easily assimilated form and are remarkable for the record content of natural BAS from fruits, vegetables and spices. Their chemical composition exceeds known world analogues and doesn't contain food admixtures.

We hope that the developed method of natural food products, cottage cheese desserts, obtained using vegetable additives as cryopastes and extracts, will be widely used.

\section{References}

[1] Dietary protein quality evaluation in human nutrition (2013). Report of an FAO Expert Consultation. Food and agriculture organization of the united nations Rome. Available at: http:/www.fao.org/ag/ humannutrition/35978-02317b979a686a57aa4593304ffc17f06.pdf

[2] Pavliuk, R. Yu., Poharska, V. V., Radchenko, L. O. et. al. (2017). Novyi napriamok hlybokoi pererobky kharchovoi syrovyny. Kharkiv: Fakt, 380.

[3] Pavliuk, R. Yu. (Ed.) (2017). Entsiklopediya pitaniya. Vol. 5. Biologicheski aktivnye dobavki. Kharkiv: Mir Knig, 406.

[4] Sinha, N. K., H’yu, I. G. (2014). Nastol'naya kniga po pererabotke plodoovoschnoy produktsii. Sankt-Peterburg: Professiya, 912.

[5] Misra, N. N., Koubaa, M., Roohinejad, S., Juliano, P., Alpas, H., Inácio, R. S. et. al. (2017). Landmarks in the historical development of twenty first century food processing technologies. Food Research International, 97, 318-339. doi: https://doi.org/10.1016/j.foodres.2017.05.001

[6] Kaprel'yants, L. V. (1997). Funktsional'nye produkty. Kyiv: Enter Prims, 312.

[7] Stringer, M., Dennis, K. (2004). Ohlazhdennye i zamorozhennye produkty. Sankt-Peterburg: Professiya, 492.

[8] Min, K., Chen, K., Arora, R. (2014). Effect of short-term versus prolonged freezing on freezethaw injury and post-thaw recovery in spinach: Importance in laboratory freeze-thaw protocols. Environmental and Experimental Botany, 106, 124-131. doi: https://doi.org/10.1016/j.envexpbot.2014.01.009

[9] James, S. J., James, C. (2014). Chilling and Freezing. Food Safety Management, 481-510. doi: https://doi.org/10.1016/b978-0-12-381504-0.00020-2

[10] Tuan Pham, Q. (2014). Freezing time formulas for foods with low moisture content, low freezing point and for cryogenic freezing. Journal of Food Engineering, 127, 85-92. doi: https://oi.org/10.1016/ j.jfoodeng.2013.12.007

[11] Pavlyuk, R., Pogarska, V., Timofeyeva, N., Bilenko, L., Stukonozhenko, T. (2016). Exploring the processes of cryomechanodestruction and mechanochemistry when devising nano-technologies for the frozen carotenoid plant supplements. Eastern-European Journal of Enterprise Technologies, 6 (11 (84)), 39-46. doi: https://doi.org/10.15587/1729-4061.2016.86968

[12] Pavlyuk, R., Pogarska, V., Balabai, K., Pavlyuk, V., Kotuyk, T. (2016). The effect of cryomechanodestruction on activation of heteropolysaccaride-protein nanocomplexes when developing nanotechnologies of plant supplements. Eastern-European Journal of Enterprise Technologies, 4 (11 (82)), 20-28. doi: https://doi.org/10.15587/1729-4061.2016.76107

[13] Pavlyuk, R., Pogarskaya, V., Cherevko, O., Pavliuk, V., Radchenko, L., Dudnyk, E. et. al. (2018). Studying the complex of biologically active substances in spicy vegetables and designing the nanotechnologies for cryosupplements and nanoproducts with health benefits. Eastern-European Journal of Enterprise Technologies, 4 (11 (94)), 6-14. doi: https://doi.org/10.15587/1729-4061.2018.133819

[14] Pavlyuk, R., Pogarska, V., Mikhaylov, V., Bessarab, O., Radchenko, L., Pogarskiy, A. et. al. (2018). The study of bas complex in chlorophyllcontaining vegetables and development of healthimproving nanoproducts by a deep processing method. Eastern-European Journal of Enterprise Technologies, 2 (11 (92)), 48-56. doi: https://doi.org/10.15587/1729-4061.2018.127158

[15] The Effect of Storage Temperature on the Ascorbic Acid Content and Color of Frozen Broad Beans and Cauliflowers and Consumption of electrical Energy during Storage (Turkish with English Abstract) (2015). Gida: Journal of Food, 11 (5). Available at: https://doaj.org/article/f6cf2689b10743ff95faa483fd8d6956

[16] Clarke, C. (2015). The Science of Ice Cream. Unilever.

[17] Ermakov, A. I., Arasimovich, V. V. (1987). Opredelenie gemitsellyuloz. Metody biohimicheskogo issledovaniya rasteniy. Moscow-Leningrad, 198-202.

[18] GOST 26889-86. Food-stuffs and food additives. General directions for determination of nitrogen content by the Kjeldahl method. 